Review Article

\title{
The diversity of citrus endophytic bacteria and their interactions with Xylella fastidiosa and host plants
}

\author{
João Lúcio Azevedo ${ }^{1}$, Welington Luiz Araújo ${ }^{2}$ and Paulo Teixeira Lacava ${ }^{3}$ \\ ${ }^{1}$ Departamento de Genética, Escola Superior de Agricultura Luiz de Queiroz, Universidade de São Paulo, \\ Piracicaba, SP, Brazil. \\ ${ }^{2}$ Departamento de Microbiologia, Instituto de Ciências Biomédicas, Universidade de São Paulo, São Paulo, \\ SP, Brazil. \\ ${ }^{3}$ Departamento de Morfologia e Patologia, Centro de Ciências Biológicas e da Saúde, Universidade Federal \\ de São Carlos, São Carlos, SP, Brazil.
}

\begin{abstract}
The bacterium Xylella fastidiosa is the causal agent of citrus variegated chlorosis (CVC) and has been associated with important losses in commercial orchards of all sweet orange [Citrus sinensis (L.)] cultivars. The development of this disease depends on the environmental conditions, including the endophytic microbial community associated with the host plant. Previous studies have shown that $X$. fastidiosa interacts with the endophytic community in xylem vessels as well as in the insect vector, resulting in a lower bacterial population and reduced CVC symptoms. The citrus endophytic bacterium Methylobacterium mesophilicum can trigger $X$. fastidiosa response in vitro, which results in reduced growth and induction of genes associated with energy production, stress, transport, and motility, indicating that $X$. fastidiosa has an adaptive response to $M$. mesophilicum. Although this response may result in reduced CVC symptoms, the colonization rate of the endophytic bacteria should be considered in studies that intend to use this endophyte to suppress CVC disease. Symbiotic control is a new strategy that uses symbiotic endophytes as biological control agents to antagonize or displace pathogens. Candidate endophytes for symbiotic control of CVC must occupy the xylem of host plants and attach to the precibarium of sharpshooter insects to access the pathogen. In the present review, we focus on interactions between endophytic bacteria from sweet orange plants and $X$. fastidiosa, especially those that may be candidates for control of CVC.
\end{abstract}

Keywords: endophytes, Citrus sinensis, Curtobacterium flaccumfaciens, Methylobacterium mesophilicum, symbiotic control.

Received: March 17, 2016; Accepted: June 09, 2016.

\section{Endophytic microorganisms and biological control}

Endophytes can be isolated from surface-disinfected plant parts or the inner plant tissues and are defined as microorganisms, mainly bacteria and fungi, that live within a plant for at least a part of their life cycle without causing apparent harm to the host (Petrini et al., 1989; Hallmann et al., 1997; Azevedo et al., 2000). A more comprehensive definition was proposed by Azevedo and Araújo (2007), who described endophytes as all microorganisms that may or may not be successfully cultured, internally colonize the host plant and do not cause apparent damage and/or visible external structures. This definition was amended by Mendes and Azevedo (2008) to divide endophytes in two types: type I, which does not produce external structures, and type

Send correspondence to João Lúcio Azevedo. Departmento de Genética, Escola Superior de Agricultura Luiz de Queiroz, Universidade de São Paulo, Av. Pádua Dias 11, PO BOX 83, Piracicaba, SP 13400-970, Brazil. E-mail: jlazevedo@usp.br
II, which produces external structures, such as nodules from nitrogen-fixing bacteria and fungi-plant mycorrhizal associations. Recently, Hardoin et al. (2015) proposed that the term "endophyte" should be used as a habitat only, not a function, including all microorganisms able to colonize the inner plant tissues.

Endophytes have been reported to contribute to host plant protection and, ultimately, survival (Sturz and Matheson, 1996; Hallmann et al., 1998; Azevedo et al., 2000; Newman and Reynolds, 2005; Rosenblueth and MartinezRomero, 2006; Reinhold-Hurek and Hurek, 2011; Suryanarayanan, 2013; Nair and Padmavathy, 2014; Podolick et al., 2015). Because endophytes colonize an ecological niche similar to that of phytopathogens, they are possible biocontrol agents (Hallmann et al., 1997; Hardoin et al., 2015). The potential for practical applications of endophytes has led to studies investigating the ability of bacteria to control both disease and insect infestations, as well as promote plant growth (Azevedo et al., 2000; Kozdrój et al.; 2004; 
Kavino et al., 2007; Podolick et al., 2015). Indeed, previous work has suggested that endophytic microorganisms have the potential to control pathogens (Sturz and Matheson, 1996; Duijff et al., 1997; Sharma and Nowak, 1998; Sturz et al., 1998; Lacava et al., 2004; 2007a), insects (Petrini et al., 1989; Azevedo et al., 2000), and nematodes (Hallmann et al., 1997). In grass, infection by endophytic fungi and alkaloid production reduced aphid feeding but had no effect on viral titers in the host plant (Ruá et al., 2013). However, the authors observed that the virulence of the viral infection was reduced in endophyte-infected plants, suggesting that although the endophyte had no effect on viral infection, the presence of the endophytes could trigger a host response that reduced virulence. The balance of this interaction among the host plant, endophytic fungi, aphids and viruses was influenced by the host and endophyte genotypes and was also driven by environmental conditions (Ruá et al., 2013; 2014).

In addition, endophytes can also accelerate seed emergence, assist in establishing the plant under adverse conditions (Chanway, 1997), and increase plant growth and development (Bent and Chanway, 1998; Lazarovits and Nowak, 1997; Pillay and Nowak, 1997; Nassar et al., 2005, Bao and Roossinck, 2011; Bezerra et al., 2013; Verma et al., 2015; Chebotar et al., 2015).

Endophytic bacteria may play a significant role in protection against plant pathogens and in the overall productivity of an agricultural ecosystem (Hallmann et al., 1997; Sturz et al., 2000). These microorganisms produce molecules that function as growth-promoting metabolites, insect-pest repellents, antimicrobials against plant pathogens, and protectants against stress (Rai et al., 2014). They can also produce unique secondary metabolites that can be exploited in pharmaceutical, agricultural and other industries (Golinska et al., 2015).

The utilization of endophytic bacteria for biotechnological purposes has recently increased, especially with regard to insect and disease control and plant growth promotion. Endophytic bacteria promote plant growth in three major ways, by synthesizing compounds that are useful to the plants, by facilitating the uptake of certain nutrients from the soil, and by controlling or preventing disease (biological control). Growth promotion mediated by endophytic bacteria occurs via several mechanisms: the synthesis of enzymes; the production of hormones such as auxin [indoleacetic acid (IAA)]; symbiotic nitrogen fixation; antagonism against phytopathogens by siderophores, chitinases or antibiotics; and the solubilization and mineralization of nutrients, particularly insoluble mineral phosphates (Lacava and Azevedo, 2013, 2014). Indeed, interactions between endophytes and plants can promote plant health and play a significant role in low-input sustainable agriculture for both food and nonfood crops. Nonetheless, an understanding of the mechanisms that enable endophytes to interact with plants is essential for realizing the biotechno- logical potential of these microorganisms (Quecine et al., 2014).

In citrus trees, the endophytic environment becomes more stable and uniform over time. This may result from selection of particular genotypes within each local microbial population (Araújo et al., 2002). Consequently, bacteria living in an endophytic environment may adapt to this more stable environment, resulting in intense interactions among the populations (Lacava et al., 2004).

Several reports highlighted the relationships among bacterial populations and suggest that CVC symptoms in citrus plants could be influenced by the population balance among Methylobacterium spp., Curtobacterium flaccumfaciens and X. fastidiosa (Araújo et al., 2002; Lacava et al., 2004, 2006b, 2007a; Ferreira Filho et al., 2012). Understanding the relationship among endophytic bacteria within sweet orange trees and $X$. fastidiosa may lead to strategies to control CVC using endophytic bacteria (Ferreira Filho et al., 2012) or inducing physiological shifts in both the host plant and microbial community that result in more balanced and stable interactions.

\section{The plant pathogen Xylella fastidiosa}

The first report of symptoms caused by what we now call Xylella fastidiosa was in 1884 in the grape-growing region of southern California (US). A disease syndrome, known today as Pierce's disease (PD), was later described in detail (Pierce, 1892). Subsequently, similar diseases were reported in many fruit tree and ornamental species, especially in North and South America (Hopkins, 1989). X. fastidiosa is a fastidious, Gram-negative, xylem-limited, rod-shaped bacterium with distinctive rippled cell walls. It is non-flagellated, does not form spores and measures 0.1-0.5 1-5 $\mu \mathrm{m}$ (Nyland et al., 1973; Bradbury, 1991). This Gram-negative bacterium was formally named only in 1987 (Wells et al., 1987). It is extremely slow-growing in culture. These traits have made the pathogen difficult to study and contributed to its previous obscurity. The taxonomic position of $X$. fastidiosa (Wells et al., 1987) is: Bacteria, Gracilicutes, aerobic rods, Category I, Group 4, Subgroup 4 A (Holt, 1994). Natural transmission occurs via insects feeding suctorially on xylem sap. Transmission efficiency varies widely among vector species. The bacterium overwinters in the xylem of the host plants as well as in weeds (Lopes et al., 2003; Wistrom and Purcell, 2005).

$X$. fastidiosa (Wells et al., 1987) resides in the xylem vessels of a broad range of perennial plants in the New World and has been shown to cause important diseases in a variety of fruit trees and vines. These include PD in grapevines (Davis et al., 1981; Hopkins and Purcell, 2002), leaf scorches in pecan (Sanderlin and Heyderich-Alger, 2000; Sanderlin and Melanson, 2006), pear (Leu and Su, 1993), plum (Raju et al., 1983), almond (Mircetich et al., 1976), mulberry (Kostka et al., 1986), elm, sycamore, oak (Hearon 
et al., 1980), maple (Sherald et al., 1987), coffee (de Lima et al., 1998), oleander and olives (Saponari et al., 2013), as well as alfalfa dwarf (Goheen et al., 1979), phony peach disease (Wells et al., 1981), periwinkle wilt (McCoy et al., 1978), and citrus variegated chlorosis (Chang et al., 1993; Hartung et al., 1994). Strains of $X$. fastidiosa have a wide host range in the native flora, where they exist without inducing symptoms of disease, and they are transmitted by common sharpshooter insects (Freitag, 1951; Freitag and Frazier, 1954).

Following the publication of the $X$. fastidiosa genome (Simpson et al., 2000), there was an increased number of articles describing new features of $X$. fastidios $a$, such as the existence of plasmids and phages and the discovery of conjugation and recombination in the species as well similarities among genomes of distinct $X$. fastidiosa strains. Bhattacharyya et al. (2002) described a whole-genome comparative analysis of three phytopathogenic strains from almond, citrus and oleander. This study demonstrated that these genomes are closely related. Van Sluys et al. (2003) described limited genomic structural variability within $X$. fastidiosa, which suggested that phylogenetic groups colonizing different host plants have similar pathogenicity mechanisms. Varani et al. (2012) showed that comparative genomic databases were an important information resource to explore the annotation, genomic features and biology of different $X$. fastidiosa strains. Other results published after the $X$. fastidiosa genome release should also be mentioned. Marques et al. (2001) described the sequence of the plasmid pXF51 from the plant pathogen $X$. fastidiosa, showing that this plasmid contained genes for conjugation, replication and mobilization but apparently had no role in pathogenesis, only in conjugative transfer. Nunes et al. (2003) constructed a microarray and evaluated the occurrence of prophages, plasmids and genomic islands (18\% of the genome). The authors showed that most of these elements are transcriptionally active and could explain the ability of $X$. fastidiosa strains to infect a wide range of plant species. Plasmids were also found and sequenced by other authors, such as Rogers and Stenger (2012). Additionally, Kung and Almeida (2011) demonstrated that recombination can occur at relatively high rates and may play a large role in shaping the genetic diversity of $X$. fastidiosa. Chen and Civerali (2008) demonstrated that phages particles are released by $X$. fastidiosa cultures for the first time, and Summer et al. (2010) carried out genomic and bacterial analyses of the phage Xfas53 and related prophages of $X$. fastidiosa. Guilhabert and Kirkpatrick (2003) successfully transformed $X$. fastidiosa using a broad host range plasmid.

However, despite the increasing knowledge of $X$. fastidiosa characteristics, the molecular mechanisms determining host plant specificity have not been elucidated (Almeida and Nunney, 2015). The interactions between $X$. fastidiosa and attacked plants were discussed in more detail in a review by Hopkins and Purcell (2002). More recently,
Almeida and Nunney (2015) reviewed the main processes that led to the emergence of the diseases caused by $X$. fastidiosa. Since 2002, it has become clear that the frequency and density of the pathogens and endophytic bacteria in citrus plants may be a result of a tripartite interaction associated with environmental conditions (Araújo et al., 2001, 2002). Therefore, in the present review, the CVC status and the molecular and ecological aspects of this tripartite interaction will be discussed. In addition, a possible strategy based on symbiotic control will be proposed.

\section{Citrus variegated chlorosis $(\mathrm{CVC})$}

Citrus variegated chlorosis (CVC) is a disease of the sweet orange [Citrus sinensis (L.)], which is caused by $X$. fastidiosa (Chang et al., 1993; Hartung et al., 1994; Schaad et al., 2004), a phytopathogenic bacterium that has been shown to infect all sweet orange cultivars (Li et al., 1997a). CVC was first reported in Brazil in 1987 and has rapidly become one of the economically most important diseases affecting sweet orange production in Brazil (Rossetti et al., 1990; Lee et al., 1991). CVC rapidly spread to most major citrus-growing areas through unregulated movement of infected nursery stock due to a previous lack of certification programs and high CVC infection rates in Brazil.

Brazil is the largest producer of citrus fruits in the world ( $25 \%$ of the total world production), supplying most of the international market with concentrated orange juice. More than $80 \%$ of these products are produced in the state of São Paulo. Approximately 15 years ago, CVC was found in at least $90 \%$ of the orchards in Brazil (Lambais et al., 2000). The incidence and severity of CVC are higher in the northern region than in the southern region of São Paulo (Ayres et al., 2001; Gonçalves et al., 2014). In 2011, more than $40 \%$ of the sampled plants in Brazil had CVC symptoms, approximately 5\% more than in 2010, showing that the disease is still increasing (www.agriculture.gov.br/arq_editor/file/camaras_exterior).

$\mathrm{CVC}$ is considered one of the most important diseases affecting the Brazilian citrus industry, and economic losses due to $\mathrm{CVC}$ can reach $\$ 120$ million per year (Bové and Ayres, 2007). In an effort to reduce losses, additional regulations have been placed on the production and commercialization of citrus seedlings. In 2003, it became mandatory in São Paulo to propagate citruses in protected, screened houses, increasing the cost of production (Carvalho, 2003). CVC affects mostly oranges (C. sinensis); it has mainly been observed on the cultivars 'Pera', 'Hamlin', 'Natal' and 'Valencia'. It occurs in trees propagated on all commonly used rootstocks in Brazil: C. limonia, C. reshni and $C$. volkameriana (Li et al., 1997c). The disease has not been observed in limes ( $C$. latifolia) or mandarins $(C$. reticulata), even when the trees were planted in severely affected orange groves (Li et al., 1997b). Some weed species are also hosts and act as reservoirs of infection (Smith et al., 1997). This disease continues to show an increase in sever- 
ity, as mentioned, with $35 \%-40 \%$ of the sweet orange trees in São Paulo, Brazil currently showing yield losses (www.fundecitrus.com.br). Citrus plants with $\mathrm{CVC}$ show a notable leaf chlorosis, similar to zinc deficiency, as the initial symptom (Laranjeira et al., 1998; Machado et al., 2006). Later symptoms include wilting, canopy dieback, necrotic leaf lesions, and undersized, hard fruit (Derrick and Timmer, 2000; Hopkins and Purcell, 2002). The causal agent of CVC has been found to be transmitted by sharpshooter leafhoppers (Cicadellidae) in Brazil (Lopes et al., 1996; Almeida and Purcell, 2003). CVC has been experimentally transmitted by 11 different sharpshooter species tested in Brazil (www.fundecitrus.com.br). Additionally, the pathogen can be transmitted through seeds ( $\mathrm{Li}$ et al., 2003). Although $X$. fastidiosa was the first plant pathogen to have its genome sequenced (Simpson et al., 2000), there is still no effective control for CVC. The pathogen is known to have an extraordinary host range among higher plants in New World ecosystems (Freitag, 1951). Interestingly, within the majority of native host plants, $X$. fastidiosa does not damage the host plant and behaves as an endophyte (Purcell and Saunders, 1999). In contrast, the horticultural crops that suffer from diseases caused by $X$. fastidiosa are those that have been introduced into New World ecosystems (Chen et al., 2000). The observation that a few asymptomatic trees persist in some infected orchards may lead to new approaches to the control of CVC. These asymptomatic plants have the same genotype as diseased plants and are located in the same grove under similar climatic and edaphic conditions, suggesting that some other factor is responsible for resistance to CVC. One factor that may influence the resistance to $\mathrm{CVC}$ is the nature of the endophytic microbial community colonizing individual $C$. sinensis plants (Araújo et al., 2002).

\section{Endophytic bacteria from citrus plants and interactions with Xylella fastidiosa}

We have focused on the interaction between members of the endophytic bacterial community, such as Methylobacterium spp. and C. flaccumfaciens, which occupy the same ecological niche as X. fastidiosa in the xylem vessels of citrus plants (Araújo et al., 2002). The genus Methylobacterium is classified in the $\alpha 2$ subgroup of the Proteobacteria and includes a group of strictly aerobic, Gram-negative, pink-pigmented, facultatively methylotrophic (PPFM) bacteria characterized by their ability to utilize single-carbon compounds, such as methanol and formaldehyde, via the serine pathway, as well as a wide range of multi-carbon growth substrates (Green, 1992; Urakami et al., 1993; Wood et al., 1998; Doronina et al., 2000, 2002; McDonald et al., 2001; Van Aken et al., 2004; Anesti et al., 2004; Van Jourand et al., 2004; Gallego et al., 2005a,b,c, 2006). In the host plant, during plant interactions, biofilm formation on surface of the root and hypocotyl of C. roseus occurred prior to endophytic colonization (Andreote et al., 2006). In addition, the authors observed that $M$. mesophilicum SR1.6/6 induced shifts in the indigenous endophytic $\alpha$ - and $\beta$-Proteobacteria populations, using DGGE techniques. In soybean, Araújo et al. (2015) observed that during the initial step of plant colonization (including plant exudate recognition and adaptation), based on transcriptomic analysis, several genes involved in membrane transport were expressed, suggesting metabolic activation in the presence of root exudate. In addition, the results showed that genes encoding proteins related to suppression of oxidative stress, such as glutathione peroxidase and glutathione synthetase, were induced, suggesting that these genes are probably related to cellular detoxification during plant root colonization. Additionally, Dourado et al. (2013) showed that bacterial density is an important characteristic during plant colonization because some genes related to metabolism, stress and pathogenesis were induced by quorum-sensing systems, indicating that plant colonization depends on bacterial coordination of events related to host recognition and stress suppression.

Araújo et al. (2001) isolated several endophytic bacteria from different citrus rootstocks and showed that Alcaligenes sp., Bacillus spp. (including B. cereus, B. lentus, B. megaterium, B. pumilus, and B. subtilis), Burkholderia cepacia, Curtobacterium flaccumfaciens, Enterobacter cloacae, Methylobacterium extorquens, and Pantoea agglomerans were the dominant species. Furthermore, the frequency of endophytic bacteria in healthy, escape, and CVC-affected Citrus sinensis plants was studied using cultivation as well as cultivation-independent methods (Araújo et al., 2002). Bacteria from the genus Methylobacterium were the most frequently isolated endophytes from CVC-symptomatic citrus plants (C. sinensis) (Araújo et al., 2002; Lacava et al., 2004, 2006a,b); however, Araújo et al. (2002) observed that M. extorquens was only isolated from CVC-affected plants while $M$. mesophilicum was isolated from healthy plants, indicating that specific Methylobacterium species may be related to the citrus plant physiological condition. Furthermore, in in vitro studies, Lacava et al. (2004) showed that $M$. mesophilicum could reduce the growth of $X$. fastidiosa, while $M$. extorquens had no effect on the $X$. fastidiosa growth. In addition, in co-inoculation experiments using Catharanthus roseus as a model plant, Lacava et al. (2006a) showed that the population of M. mesophilicum was lower in the presence of $X$. fastidiosa compared to inoculation of this endophytic bacterium alone and that the population of $X$. fastidiosa was in turn reduced by the inoculation of M. mesophilicum. The results suggest that these bacteria could compete for nutrients and colonization sites inside the host plant. In fact, using microarray analysis, Dourado et al. (2015) showed that the M. mesophilicum strain SR1.6/6 directly down-regulated genes related to bacterial growth, such as DNA replication and protein syn- 
thesis genes (50S ribosome protein and topoisomerase enzyme genes) in $X$. fastidiosa. In contrast, $C$. flaccumfaciens strain ER1/6, another citrus endophyte, up-regulated genes related to protein synthesis. Additionally, despite the $X$. fastidiosa growth reduction, genes related to energy generation (fumarate hydratase and dihydrolipoamide dehydrogenase from the Krebs cycle) were up-regulated in $X$. fastidiosa in response to M. mesophilicum, suggesting that although the CVC causal agent is not growing, energy is necessary to maintain the interaction profile, including genes related to stress response and membrane transporters.

Therefore, the development of CVC symptoms in citrus plants could be influenced by the population balance among the endophytic bacteria Methylobacterium spp. and X. fastidiosa (Lacava et al., 2004; Dourado et al., 2015) and environmental conditions, which affect the host physiology and response to the presence of the microbial community.

The genus Curtobacterium has been defined by Yamada and Komagata (1972) as Gram-positive aerobic bacteria, with some so-called motile brevibacteria. Curtobacterium strains have been isolated from rice and other plants, and C. flaccumfaciens, in particular, is a wellestablished plant pathogen (Collins and Jones, 1983). However, Curtobacterium has been isolated as an endophyte from many crops, including red clover (Sturz et al., 1998), potato (Sturz and Matheson, 1996), yam (Tor et al., 1992), prairie plants (Zinnier et al., 2002), and citrus (Araújo et al., 2001). Several reports have indicated that $C$. flaccumfaciens can function as a biological control agent against many pathogens and may function either by triggering induced systemic resistance (Raupach and Kloepper, 1998) or by antibiosis (Sturz and Matheson, 1996).

The bacterium $C$. flaccumfaciens has been more frequently isolated from CVC-asymptomatic than from CVC-symptomatic orange (C. sinensis) and tangerine (Citrus reticulata) plants (Araújo et al., 2002; Lacava et al., 2004), and it was also suggested, based on in vitro interaction experiments, that the growth of $X$. fastidiosa could be inhibited by endophytic $C$. flaccumfaciens. Symptoms of $X$. fastidiosa infection in C. roseus, such as shortened internodes, reduced flowering and stunting and chlorosis of leaves with occasional scorch symptoms, were reduced or prevented entirely by co-inoculation with $C$. flaccumfaciens (Lacava et al., 2007a). Madagascar periwinkle, C. roseus (L.) G. Don, has been identified as an excellent experimental host for $X$. fastidiosa (Monteiro et al., 2001). Symptoms of $X$. fastidiosa infection in periwinkle include shortened internodes, reduced flowering, stunting, and leaf chlorosis with occasional scorch symptoms and wilting (Monteiro et al., 2001). In comparison with the sweet orange, the Madagascar periwinkle is significantly easier to maintain in a greenhouse, and symptom induction following inoculation with $X$. fastidiosa is both more rapid and more reliable. The Madagascar periwinkle has also been utilized to study the interactions between $X$. fastidiosa and other endophytic bacteria (Lacava et al., 2006a, 2007a).

\section{Biological control of CVC}

Lacava et al. (2004) reported that the growth of $X$. fastidiosa was inhibited by endophytic $C$. flaccumfaciens in vitro, and Lacava et al. (2007a) demonstrated that $C$. flaccumfaciens reduced the severity of disease symptoms when co-inoculated with $X$. fastidiosa in periwinkle $(C$. roseus) plants.

Isolation and denaturing gradient gel electrophoresis (DGGE) techniques revealed several genera of bacteria as colonizers of glassy-winged sharpshooter (GWSS) heads. These bacteria were identified by $16 \mathrm{~S}$ sequencing and included M. extorquens and C. flaccumfaciens. The GWSS Homalodisca vitripennis Germar (Hemiptera: Cicadellidae) [formerly $H$. coagulata (Takiya et al., 2006)] is the most widespread sharpshooter insect vector of $X$. fastidiosa in the United States. In addition, Kirkpatrick and Wilhelm (2007) have also isolated strains of $C$. flaccumfaciens as part of the endophytic bacterial community of grapevines in California. In Brazil, $C$. flaccumfaciens is consistently isolated as an endophytic bacterium from citrus plants (Araújo et al., 2002; Lacava et al., 2004).

It is likely that endophytic bacteria are introduced into sweet orange trees by sharpshooter insects in the same manner as X. fastidiosa. Gai et al. (2011) showed that Curtobacterium sp. were the most important bacteria colonizing the heads of the insect vectors of $X$. fastidiosa in Brazil.

Curtobacterium flaccumfaciens was shown to play an important role in the prevention of CVC symptoms in citrus trees (Araújo et al., 2002; Lacava et al., 2004, 2007a). The presence of the citrus endophyte Curtobacterium sp. in insect heads could explain why the transmission efficiency of $X$. fastidiosa by vectors is low (5 to $10 \%$ ) compared to the transmission of $X$. fastidiosa subsp. fastidiosa by GWSS, which transmit PD (45\%) (Krügner et al., 2000; Redak et al., 2004).

Endophytic bacteria could influence disease development by reducing the efficiency of transmission by insects due to competition with pathogens in host plants and also in insect foreguts (Gai et al., 2011). In addition, the bacterial communities in the foregut of insect vectors of $X$. fastidiosa change with time and environmental conditions and in different insect species. However, because members of the genus Curtobacterium were consistently detected in the insect vectors of $X$. fastidiosa (Gai et al., 2011), they may be candidates for biological control of $X$. fastidiosa, which requires endophytic bacteria (Lacava et al., 2007a) that can colonize both the insect vectors of CVC and citrus plants. 


\section{Symbiotic control (SC)}

The technique of paratransgenesis was developed as a novel method to create conditions that render insect vectors incompetent. The symbiotic control (SC) strategy employs both paratransgenic (defined below) and non-recombinant methods to control disease or health problems. In some cases, these solutions may result in competitive displacement of the pathogen with a more benign microbe.

Paratransgenesis was developed to prevent the transmission of pathogens from insect vectors to humans (Beard et al., 1998, 2001, 2002; Rio et al., 2004; Hurwitz et al., 2011). The key concept in paratransgenesis is the genetic alteration of symbiotic microbes that are carried by insects (therefore, they are paratransgenic insects). The genetic alterations of the symbiotic microbes are designed to increase their competitiveness in the insect vector at the expense of the pathogen. This overall strategy of disease prevention is an example of SC and is a variation on the theme of symbiotic therapy (Ahmed, 2003; Hurwitz et al., 2011). Genetic manipulation has fitness costs that must be factored in to the application (Durvasula et al., 1997; Miller, 2007, 2011).

The key to $\mathrm{SC}$, and therefore paratransgenesis, is to find a local candidate microbe with an existing association with the pathosystem that is being investigated. The local candidate microbe should occupy the same niche as, or have access to, the target pathogen or condition (Durvasula et al., 1997; Hurwitz et al., 2011). The local origin of the biocontrol microbe in SC differs from classical biological control, where microbes, herbivores, parasites or predators are sought from outside the local ecosystem for establishment in the local ecosystem to control a pest, such as a plant or invertebrate (Miller, 2011; Hurwitz et al., 2011). In SC, all elements originate at the local site and have already co-evolved with and been established in the pathosystem; foreign exploration is not only unnecessary but also most likely counter-productive. Because of these strict requirements, a suitable symbiotic candidate may not always be found or may not be amenable to practical manipulation (Miller, 2011; Hurwitz et al., 2011).

Microbes chosen for symbiotic control must be able to pass subsequent regulatory scrutiny (Miller, 2011; Bourtzis et al., 2012). Once a candidate symbiont is identified as a control agent for paratransgenesis, all genetic or other manipulations can be local. Indeed, a symbiotic control or paratransgenic solution developed for a specific location may not be suitable for another site or condition elsewhere (Durvasula et al., 1999, 2003; Miller, 2011).

Once a microbe is identified as having potential for symbiotic or paratransgenic control, it is studied to define the requirements for culture and reintroduction into the pathosystem and the suitability for genetic alteration, if necessary. The methods selected must be adaptable to ordinary practices in the target area. In the case of paratransgenic control, a gene or genes to be introduced into the endosymbiont to influence its interaction with the pathogen must be identified. Beard et al. (2001) isolated and characterized symbiont bacteria from various triatomine species, which are vectors of Chagas disease, and developed a method for genetically transforming them. These authors reintroduced them into triatomine species, thereby producing stable paratransgenic insects that express heterologous gene products.

Pierce's disease (PD) was first detected in Southern California in 1884, where it destroyed approximately 40,000 acres of grapes in Anaheim, CA during a 5-year outbreak (Pierce, 1892; Goodwin and Purcell, 1992). After this devastating experience, PD became only an occasional concern to West Coast viticulture for decades until the mid-1990s, when the GWSS became established in California. The GWSS is a major concern for horticultural industries beyond viticulture due to its ability to transmit $X$. fastidiosa strains causing scorch diseases in a number of host plants, including $X$. fastidiosa subsp. fastidiosa that causes PD in grapevines (Wistron and Purcell, 2005). As with other sharpshooter insects, $H$. vitripennis is a xylophagous insect that feeds on hundreds of plant species (Purcell and Hopkins 1996; Purcell and Saunders 1999); citrus is one of its preferred hosts (Blua et al., 2001). Perring et al. (2001) demonstrated a relationship between PD incidence in grapes and the proximity of vineyards to citrus orchards. This leafhopper, which can serve as a vector of $X$. fastidiosa, has the capacity to feed on more than 70 different plant species and can survive winter temperatures as low as $-6^{\circ} \mathrm{C}$ (Park et al., 2006). Moreover, compared with other $X$. fastidiosa-carrying insects associated with PD that are native to California, GWSS has a longer flight range (up to a quarter mile). These traits make the GWSS a very serious threat to the wine industry of southern and central California (Castle et al., 2005). Indeed, since the first identification of GWSS in California vineyards, programs aimed at controlling the dissemination of this insect to prevent PD outbreaks have involved more than US\$160 million of direct investments (http://www.cdfa.ca.gov/phpps/pdcp/). Control of any of the GWSS-transmitted diseases of horticultural crops in California by an SC or paratransgenic approach would be of immediate interest to other industries as well. The objective or rationale for developing a method of SC for PD is to disrupt vector transmission with minimal effects on other crops. SC would be available to local vineyards for local control instead of the area-wide treatments of alternative host plants that are currently used. Treatment of citrus with systemic insecticides for GWSS to reduce the chance of acquiring and spreading pathogens in adjacent vineyards cannot be considered a long-term solution. SC would be more selective and have fewer side effects than other biological control practices. The SC organisms inhabit the xylem fluid of the target plants yet do not contaminate the berries of the grapevines. It remains to be determined if one treatment would be effective for an entire season (Miller, 2011). 
Three potential bacterial candidates, Alcaligenes sp., Chryseomonas sp., and Ralstonia sp., for SC of PD were collected from GWSS in southern California (Bextine et al., 2004). All were endophytes transmitted to different host plants by GWSS in a manner analogous to the pathogen; thus, the candidates had access to the pathogen in host plants or in the insect vector, providing the needed access. Alcaligenes denitrificans var. xylosoxidans (Axd) was selected for further development because the endophytic bacterium should have most of the requirements for a successful paratransgenesis strategy such as: a) a population of microbes that is amenable to culture and genetic manipulation in vitro must exist within a disease-transmitting vector; b) facile methods for isolating and transforming the endophytic bacteria must be present; c) transformation of the symbiotic/endophytic bacteria must result in stable mutants; d) genetic manipulation of the bacteria should not affect their symbiotic functions in the host vector; e) genetic manipulation of symbiotic bacteria should not render them virulent, either to the target vector or other organisms in the environment. Furthermore, bacteria chosen as genedelivery vehicles must not be pathogens themselves.

Successful delivery to and colonization of Axd in the foregut regions of GWSS suggest that a paratransgenic approach to manage, prevent, and/or control Pierce's disease is possible (Bextine et al., 2004).

Lacava et al. (2007b) used isolation and denaturing gradient gel electrophoresis (DGGE) techniques to identify several genera of bacteria as colonizers of the heads of GWSS collected in orange groves. As identified by $16 \mathrm{~S}$ rRNA sequencing, these included Bacillus, Cryocola, Microbacterium, Micrococcus and Pedobacter. In addition, Methylobacterium extorquens, Curtobacterium flaccumfaciens, Baumannia cicadellinicola and various Pseudomonas and Wolbachia species were found. Of these genera, Bacillus, Pseudomonas, Methylobacterium and Curtobacterium were previously described as endophytes that are able to colonize citrus plants. The work of Araújo et al. (2002) strongly suggested that there are interactions among Methylobacterium spp., C. flaccumfaciens and X. fastidiosa. These results reinforced the idea that all of these bacteria could interact in the insect vector as well as in the host plant.

Furthermore, Lacava et al. (2004) suggested that CVC symptoms in citrus plants could be influenced by the interactions among these three species. In a study of the diversity of bacterial communities associated with GWSS foreguts, they used culture-dependent methods as well as procedures based on sequence polymorphisms (DGGE) of the 16S rRNA gene in total DNA extracted from GWSS foreguts. Lacava et al. (2007b) suggested that the diversity profiles obtained with culture-dependent (isolation in culture) techniques indicated a low bacterial diversity. However, the same authors described higher bacterial diversity when using PCR-DGGE, a culture-independent method.
These results from Lacava et al. (2007b) showed that PCR-DGGE is suitable for the analysis of bacterial diversity in GWSS heads. In the future, species such as $C$. flaccumfaciens and Methylobacterium spp., found as part of the bacterial community in GWSS, could be investigated as potential candidates for use in an SC or SC paratransgenic-based strategy to control the spread of $X$. fastidiosa.

Using methods perfected in previous studies (Lampe et al., 1999, 2000), Axd was genetically altered to contain a DsRed fluorescent marker gene in the chromosome (Bextine et al., 2004) to demonstrate the ability of DsRed Axd to colonize the cibarial region of the GWSS foregut for up to 5 weeks post-exposure. Axd was shown to occupy the same region in the foregut as the pathogen X. fastidiosa (Bextine et al., 2004). DsRed Axd was transmitted by GWSS and colonized various plants (Bextine et al., 2004, 2005). DsRed Axd could be introduced into grapevines by misting the leaves, by soil drenching or by direct injection into the stem of the grapevine. Interestingly, Axd appeared to be better adapted to citrus than to grapevine (Bextine et al., 2005). Indeed, the original samples of GWSS from southern California were obtained from citrus groves in the Agricultural Operations plots at the University of California, Riverside; therefore, it is likely that the endophytes in the GWSS originally came from citrus. Bextine et al. (2004) describe the successful delivery of Axd to, and the colonization of, the foregut of GWSS. These results suggest that a paratransgenic approach to manage, prevent, and/or control PD by SC may be possible.

A number of candidate antimicrobial peptides were screened against $X$. fastidiosa (Kuzina et al., 2006). In this study, the authors showed that antibiotics and antimicrobial peptides have some activity against $X$. fastidiosa and may have applications in protecting plants from developing PD. The potential use of these antimicrobial peptides in the protection of grapevines will depend on the development of a delivery system, such as SC (Kuzina et al., 2006). Additionally, Lampe et al. $(1999,2000)$ further screened single-chain antibodies from a phage antibody library for the ability to bind the coat protein of $X$. fastidiosa. These authors selected an antibody fragment, designated S1, that was specific to the strain of $X$. fastidiosa causing PD and did not recognize closely related $X$. fastidiosa strains.

Azizi et al. (2012) presented a simple robust approach for the generation of panels of recombinant single-chain antibodies against the surface-exposed elements of $X$. fastidiosa (PD) that may have potential use in diagnosis and/or disease transmission blocking studies. In vitro combinatorial antibody ribosome display libraries were assembled from immunoglobulin transcripts rescued from spleens of mice immunized with heat-killed $X$. fastidiosa. The libraries were used in a single round of selection against an outer membrane protein, MopB, resulting in the isolation of a panel of recombinant antibodies. The potential use of selected anti-MopB antibodies was demonstrated 
by the successful application of the 4XfMopB3 antibody in an enzyme-linked immunosorbent assay (ELISA), a western blot assay, and an immunofluorescence assay (IFA). These immortalized in vitro recombinant single-chain antibody libraries generated against heat-killed X. fastidiosa are a resource for the PD research community that may be readily accessed for the isolation of antibodies against a plethora of $X$. fastidiosa surface-exposed antigenic molecules.

Recently, Arora et al. (2015) reported a novel strategy for the delivery of genetically engineered bacteria in a paratransgenic system that targets the glassy-winged sharpshooter (Homalodisca vitripennis), an insect vector of grapes and citrus that transmits the phytopathogen $X$. fastidiosa (Dandekar et al., 2012; Rathe et al., 2014). Using simple and inexpensive materials for bioencapsulation (Weinbreck et al., 2010; Burgain et al., 2011) of the engineered symbiotic bacterium, Pantoea agglomerans, they demonstrated targeting of the sharpshooter $H$. vitripennis under controlled conditions with an alginate hydrogel that is tuned to release its bacterial payload during xylem flow into the foregut of the insect. By deploying a microencapsulation system that permits gated delivery of the bacterial payload to the arthropod, while greatly minimizing release in the environment, these authors concluded that robust field-applicable technologies for paratransgenic control of arthropod-borne diseases will be possible. According to these authors, this is the first example of the use of microencapsulation to deliver recombinant bacteria to an insect gut. They demonstrated that transgenic symbiotic bacteria can be delivered to the appropriate physiological niche within a disease-transmitting arthropod. Additionally, this platform may be expanded to deliver recombinant bacteria to other disease-transmitting arthropod vectors, thus facilitating field use of paratransgenic control.

\section{Strategy of symbiotic control for CVC}

The key to symbiotic control is finding a candidate microbe with an existing association to the ecosystem that includes the problem or condition under investigation and that occupies the same niche as or has access to the target pathogen (Miller, 2011). Bacteria of the genus Methylobacterium are known to occupy the same niche as X. fastidiosa inside citrus plants (Araújo et al., 2002; Lacava, et al., 2004). During feeding, insects could acquire not only the pathogen but also endophytes from host plants. Gai et al. (2009) and Gai et al. (2011) reported the localization of the endophytic bacterium M. mesophilicum in the $C$. roseus model plant system and the transmission of this endophyte by Bucephalogonia xanthophis, a sharpshooter insect vector of $X$. fastidiosa.

Methylobacterium mesophilicum, originally isolated as an endophytic bacterium from citrus plants (Araújo et al., 2002), was genetically transformed to express GFP (Gai et al., 2009). The GFP-labeled strain of $M$. mesophilicum was inoculated into C. roseus (model plant) seedlings and was observed colonizing its xylem vessels. The transmission of M. mesophilicum by B. xanthophis was verified with insects feeding on fluids containing the GFPlabeled bacterium. Forty-five days after inoculation, the plants exhibited endophytic colonization by $M$. mesophilicum, confirming this bacterium as a nonpathogenic, xylem-associated endophyte (Gai et al., 2009). These data demonstrate that M. mesophilicum not only occupies the same niche as X. fastidiosa inside plants but also may be transmitted by B. xanthophis. The transmission, colonization and genetic manipulation of M. mesophilicum are prerequisites for it to potentially be used for paratransgenic SC to interrupt transmission of $X$. fastidiosa by insect vectors. We propose M. mesophilicum as a candidate for a paratransgenic SC strategy to reduce the spread of $X$. fastidiosa. It is known that $X$. fastidiosa produces a fastidian gum (da Silva et al., 2001), which may be responsible for the obstruction of xylem in affected plants (Lambais et al., 2000); therefore, the production of endoglucanase by genetically modified endophytic bacteria may transform the endophytes into symbiotic control agents for CVC (Ferreira Filho et al., 2012). Azevedo and Araújo (2003) have used the replicative vector pEGLA160 to produce genetically modified Methylobacterium expressing antibiotic resistance and endoglucanase genes. Furthermore, other strategies can be evaluated, such as the production of genetically modified Methylobacterium to secrete soluble anti-Xylella proteins in citrus. Lampe et al. (2006) suggested a similar strategy with the Escherichia coli $\alpha$-hemolysin system for use in Axd to secrete soluble anti-Xylella protein effectors in grapevines and GWSS. Additionally, Lampe et al. (2007) suggested the evaluation of proteins secreted from the grapevine bacterial symbiont $P$. agglomerans for use as secretion partners of anti-Xylella protein effectors. One strategy that can be adopted as the next step for SC control of CVC is producing a genetically modified endophytic bacterium, such as Methylobacterium, to secrete anti-Xylella protein effectors.

Another strategy to control $X$. fastidiosa is to degrade the EPS (exopolysaccharides) formed by this plant pathogen that are directly related to biofilm formation. In $X$. fastidiosa, the fastidian gum may be directly linked to pathogenicity (da Silva et al., 2001) because it may be involved in the biofilm formation required for the attachment and survival of this bacterium in xylem vessels and the sucking pumps of the insect vectors. A lack of EPS would therefore prevent the plant symptoms caused by vessel occlusion (and/or embolism) and the spread of the disease as well (da Silva et al., 2001). Based on the premise of symbiotic control, Ferreira Filho et al. (2012) genetically modified the citrus endophytic bacterium Methylobacterium extorquens, strain AR1.6/2, and evaluated its capacity to colonize a model plant and its interaction with X. fastidiosa. The strain AR1.6/2 was genetically transformed to express 
heterologous GFP and endoglucanase A (EglA), generating the strains ARGFP and AREglA, respectively. Using fluorescence microscopy, it was shown that ARGFP was able to colonize the xylem vessels of the $C$. roseus seedlings. Using scanning electron microscopy, it was observed that AREglA and $X$. fastidiosa may co-inhabit the $C$. roseus vessels. $M$. extorquens was observed in the xylem with the phytopathogen $X$. fastidiosa and appeared to cause a decrease in biofilm formation. AREglA stimulated the production of the resistance protein catalase in the inoculated plants. These results demonstrate the successful transformation of AR1.6/2 to generate two different strains with a different gene and also indicate that AREglA and $X$. fastidiosa could interact inside the host plant, suggesting a possible strategy for the symbiotic control of CVC disease.

According to Ferreira Filho et al. (2012), the endophytic AR1.6/2 expressing the EglA or gfp genes showed most of the prerequisites listed by Durvasula et al. (2003) and Miller (2011) for a successful strategy of symbiotic control. For example, the AR1.6/2 strain that colonized citrus plants is amenable to isolation, culturing and transformation with foreign genes, and the heterologous expression of GFP and EglA by AR1.6/2 did not affect its growth and survival inside the host.

\section{Conclusions and Future Perspectives}

Our strategy is similar to that developed by Bextine et al. (2004) for a paratransgenic strategy for SC of PD in grapevines. Bextine et al. (2004) suggested that the genus Alcaligenes, an endophytic bacterium that can colonize the GWSS vector of $X$. fastidiosa, would be a candidate for paratransgenic SC of PD in the USA. We believe that the endophytic bacterium M. mesophilicum from citrus plants is likewise a candidate for paratransgenic SC of CVC. Our results indicate that this endophyte colonizes the same niche as X. fastidiosa in citrus plants (Araújo et al., 2002; Lacava et al., 2004, 2006a; Andreote et al., 2006). M. mesophilicum is also transmitted by an insect vector of $X$. fastidiosa (Gai et al., 2009).

Bacteria chosen as gene delivery vehicles for paratransgenesis SC must not be pathogens themselves. $M$. mesophilicum is not a pathogen, and several requirements for a successful paratransgenesis SC strategy as described by Durvasula et al. (2003) and Miller (2011) have been demonstrated: a) M. mesophilicum is amenable to culture and genetic manipulation in vitro; b) facile methods for isolating and transforming the endophytic bacteria have been developed; c) transformation of the symbiotic/endophytic bacteria has resulted in mutants that were stable in planta. Future genetic manipulation of $M$. mesophilicum to achieve paratransgenic SC should not affect its symbiotic functions in the plant host and insect vector, and genetic manipulation of symbiotic bacteria should not render them virulent, either to the host plant or target.
C. flaccumfaciens is also a candidate for biological control of CVC. Interaction and antagonism between $C$. flaccumfaciens and $X$. fastidiosa was strongly indicated on the basis of the frequency of $C$. flaccumfaciens isolation from sweet orange (Araújo et al., 2002). In addition, in vitro interactions between $X$. fastidiosa and $C$. flaccumfaciens have been described, including the inhibition of $X$. fastidiosa growth by cell-free supernatants of nutrient medium in which $C$. flaccumfaciens had been grown (Lacava et al., 2004). Additionally, Lacava et al. (2007a) demonstrated that $C$. flaccumfaciens interacted with $X$. fastidiosa in $C$. roseus and reduced the severity of the disease symptoms induced by $X$. fastidios $a$ in this model plant to study the interaction of this plant pathogen and endophytic bacteria (Monteiro et al., 2001; Lacava et al., 2006a). The ability of $C$. flaccumfaciens to colonize plant tissues in the presence of $X$. fastidios $a$ and the reduction of disease symptoms caused by $X$. fastidiosa (Lacava et al., 2007a) are prerequisites for the use of this endophytic bacterium as a biocontrol agent. Because members of the genus Curtobacterium were consistently detected in the insect vectors of X. fastidiosa (Gai et al., 2011), they fulfill another requirement of candidates for biological control of $X$. fastidiosa (Lacava et al., 2007a), i.e., they can colonize both the insect vectors of $X$. fastidios $a$ and citrus plants. In the case of biocontrol of $X$. fastidiosa and CVC disease, it would be desirable if $C$. flaccumfaciens could be transmitted by budwood, but this has yet to be demonstrated. The reduction of disease symptoms caused by $X$. fastidiosa in the presence of $C$. flaccumfaciens may be attributable to direct killing of $X$. fastidiosa by $C$. flaccumfaciens. Consistent with this hypothesis, three bacteriocins showing activity against $X$. fastidiosa have been described in $C$. flaccumfaciens (Cursino, 2005, PhD thesis, University of São Paulo, Piracicaba, São Paulo, Brazil,).

We propose two complementary strategies for control of CVC using endophytic bacteria from citrus plants. We suggest the endophytic bacterium $C$. flaccumfaciens as a classical biological control agent and the endophytic bacterium M. mesophilicum as a qualified candidate for a paratransgenic SC strategy. The details of these strategies are summarized in Figure 1.

In addition to paratransgenic processes, the balance among endophytic microorganisms and $X$. fastidiosa is very important in the control of CVC. Approximately 15 years ago, a study conducted by the Microbial Genetics group in the Department of Genetics at Luiz de Queiroz College of Agriculture, University of São Paulo (ESALQ/USP), Brazil (Araujo et al., 2001, 2002) showed that in the same citrus plantations, $X$. fastidiosa is found in both symptomatic (showing disease symptoms) and asymptomatic plants (healthy plants). Although no genetic differences were found in these plants, distinctions were found in the composition of their endophytic bacteria. Bacteria of the genera Curtobacterium and Methylobacterium 


\section{Strategies of control of CVC using endophytes}

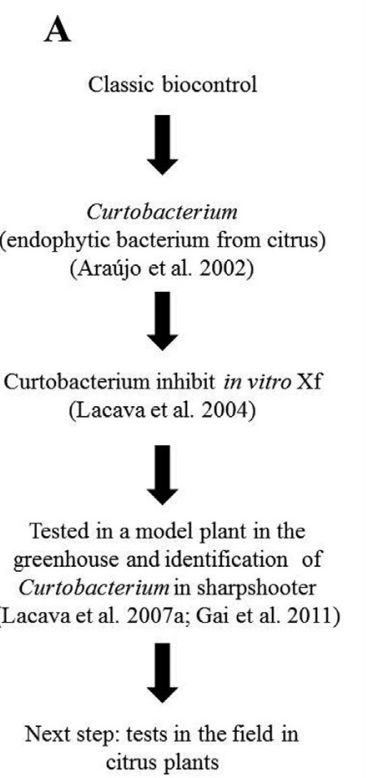

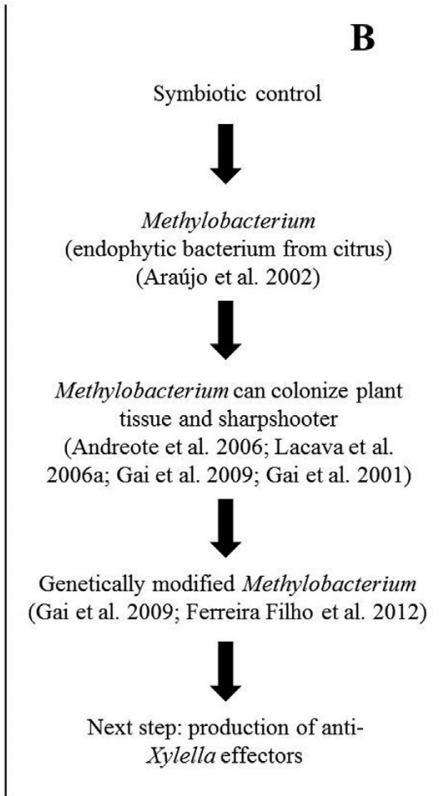

Figure 1 - Hypotheses and strategies to control citrus variegated chlorosis (CVC) using endophytic bacteria from citrus plants. (A) We suggest the endophytic bacterium Curtobacterium flaccumfaciens as a classical biological control agent. $C$. flaccumfaciens has the ability to colonize plant tissues in the presence or absence of Xylella fastidiosa (Xf). This is a prerequisite for the use of this bacterium as a biocontrol agent. The data indicate that $C$. flaccumfaciens interacted with $X$. fastidiosa in Catharanthus roseus and reduced the severity of the disease symptoms induced by $X$. fastidiosa (Araújo et al., 2002; Lacava et al., 2004, ; Lacava et al., 2007a; Gai et al., 2011). (B) Additionally, the endophytic bacterium Methylobacterium has been suggested as a qualified candidate for a paratransgenic symbiotic control (SC) strategy because there have been reports on the transmission, colonization and genetic manipulation of Methylobacterium, which are prerequisites for the potential use of this bacteria to interrupt transmission of $X$. fastidiosa, the bacterial pathogen causing CVC, by insect vectors (Araújo et al., 2002; Andreote et al., 2006; Lacava et al., 2006a; Gai et al. 2009, 2011; Ferreira Filho et al., 2012). distinguished the endophytic communities of healthy and diseased plants, respectively. There may be many causes for this endophytic imbalance, including the use of agricultural chemical products, intensive cultures, distinct agricultural management and other abiotic and biotic factors (Laranjeira et al., 2005). It appears that the balance among endophytes, which has been maintained for thousands of years by co-evolution, can be altered, and some endophytic bacteria, such as X. fastidiosa, may become pathogenic due to this endophytic imbalance (Figure 2). Similar cases have been found; Vitis vinifera plants also display differences in disease severity and symptoms, and this was shown to be due to the presence of endophytic fungi, such as Cochliobolus sp., which inhibited X. fastidiosa by producing the antimicrobial radicinin. The absence of these fungi may result in the emergence of $X$. fastidios $a$ as a pathogen (Aldrich et al., 2015). Additionally, studies (Dourado et al., 2013, 2015; Lacava et al., 2004, 2006a) have shown that the development of CVC symptoms in citrus plants could be a result of an unbalanced endophytic population, including Methylobacterium spp. and X. fastidiosa. Therefore, the understanding of this interaction will allow the development of potential strategies to prevent CVC and other diseases caused not only by $X$. fastidiosa but also by other phytopathogens and physiological shifts, which may be due to the disequilibrium in the microbial community that is induced by agricultural management during crop production.

\section{Acknowledgments}

The authors thank the Fundação de Amparo à Pesquisa do Estado de São Paulo (FAPESP) for the financial support (grants: 98/16262-2; 02/08786-9; 02/14143-3; 06/55494-4; 12/24217-6) and fellowships (process No.

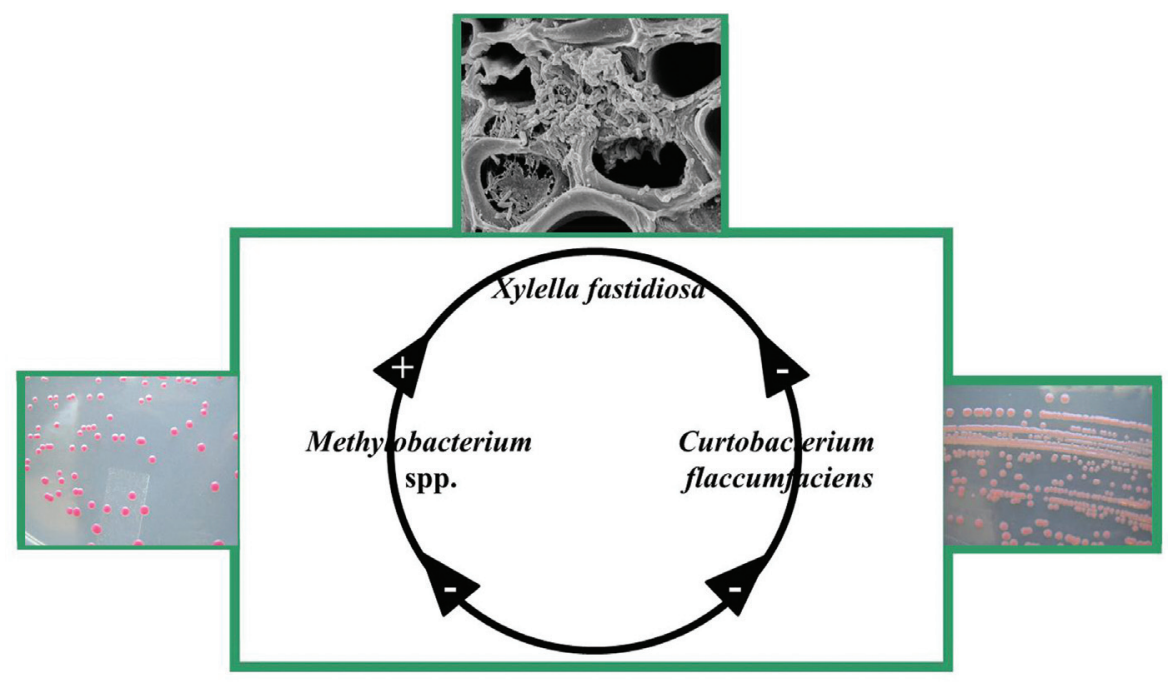

Figure 2 - Balanced interactions among endophytic bacteria from Citrus sinensis and Xylella fastidiosa, the causal agent of citrus variegated chlorosis. Photos of endophytic strains of Methylobacterium and Curtobacterium grown in Petri dishes by the authors. Photo of scanning electron micrograph of the bacterium $X$. fastidiosa by E. W. Kitajima, ESALQ/USP/Brazil (http://aeg.lbi.ic.unicamp.br/xf/). 
00/08498-8; process No. 00/10699-1; process No 00/10721-7; process No. 00/14987-1).

\section{References}

Ahmed FE (2003) Genetically modified probiotics in foods. Trends Biotechnol 21:491-497.

Aldrich TJ, Rolshausen PE and Roper MC (2015) Radicinin from Cochliobolus sp. inhibits Xylella fastidiosa the causal agent of Pierce's disease in grapevine. Phytochemistry 116:130137.

Almeida RPP and Purcell AH (2003) Transmission of Xylella fastidiosa to grapevines by Homalodisca coagulata (Hemiptera: Cicadellidae). J Econ Entomol 96:264-271.

Almeida RPP and Nunney L (2015) How do plant diseases caused by Xylella fastidiosa emerge. Plant Dis 99:1457-1467.

Andreote FD, Lacava PT, Gai CS, Araújo WL, Maccheroni Jr. W, Van Overbeek LS, Van Elsas JD and Azevedo JL (2006) Model plants for studying the interaction between Methylobacterium mesophilicum and Xylella fastidiosa. Can J Microbiol 52:419-426.

Anesti V, Vohra J, Goonetilleka S, McDonald IR, Sträubler B, Stackebrandt E, Kelly DP and Wood AP (2004) Molecular detection and isolation of facultatively methylotrophic bacteria, including Methylobacterium podarium sp. nov., from the human foot microflora. Environ. Microbiol 6:820-830.

Araújo WL, Maccheroni Jr W, Aguilar-Vildoso CI, Barroso PAV, Saridakis HO and Azevedo JL (2001) Variability and interactions between endophytic bacteria and fungi isolated from leaf tissues of citrus rootstocks. Can J Microbiol 47:229236.

Araújo WL, Marcon J, Maccheroni Jr W, Van Elsas JD and Azevedo JL (2002) Diversity of endophytic bacterial populations and their interaction with Xylella fastidiosa in citrus plants. Appl Environ Microbiol 68:4906-4914.

Araújo WL, Santos DS, Dini-Andreote F, Salgueiro-Londoño JK, Camargo-Neves AA, Andreote FD and Dourado MN (2015) Genes related to antioxidant metabolism are involved in Methylobacterium mesophilicum-soybean interaction. Antonie van Leeuwenhoek. 108:951-963.

Arora AK, Forshaw A, Miller TA and Durvasula R (2015) A delivery system for field application of paratransgenic control. BMC Biotechnol 15:e59.

Ayres AJ, Gimenes-Fernandes N and Barbosa JC (2001) Intensity of the citrus variegated chlorosis in the state of São Paulo and south of Triangulo Mineiro. Summa Phytopathol 27:189-197.

Azevedo JL and Araújo WL (2003) Genetically modified crops: Environmental and human health concerns. Mutat Res 544:223-233

Azevedo JL and Araújo WL (2007) Diversity and applications of endophytic fungi isolated from tropical plants. In: Ganguli BN and Deshmukh SK (eds) Fungi: Multifaceted Microbes. Anamaya Publishers, New Delhi, pp 189-207.

Azevedo JL, Maccheroni Jr W, Pereira JO and Araújo WL (2000) Endophytic microorganisms: A review on insect control and recent advances on tropical plants. Electron J Biotechnol 3:40-65.

Azizi A, Arora A, Markiv A, Lampe DJ, Miller TA and Kanga AS (2012) Ribosome display of combinatorial antibody libraries derived from mice immunized with heat-killed Xylella fastidiosa and the selection of MopB-specific single-chain antibodies. Appl Environ Microbiol 78:2638-2647.

Bao XD and Roossinck MC (2011) Multiplexed interesting virus of endophytic fungi. Adv Virus Res 80:32-58.

Beard CB, Durvasula RV and Richards FF (1998) Bacterial symbiosis in arthropods and the control of disease transmission. Emerg Infect Dis 4:581-591.

Beard CB, Dotson EM, Pennington PM, Eichler S, Cordon-Rosales C and Durvasula RV (2001) Bacterial symbiosis and paratransgenic control of vector borne Chagas disease. Int $\mathrm{J}$ Parasitol 31:621-627.

Beard C, Cordon-Rosales C and Durvasula R (2002) Bacterial symbionts of the triatominae and their potential use in control of Chagas Disease transmission. Annu Rev Entomol 47:123-141

Bent E and Chanway CP (1998) The growth-promoting effects of a bacterial endophyte on lodgepole pine are partially inhibited by the presence of other rhizobacteria. Can J Microbiol 44:980-988.

Bextine B, Lauzon C, Potter S, Lampe D and Miller TA (2004) Delivery of a genetically marked Alcaligenes sp. to the glassy-winged sharpshooter for use in a paratransgenic control strategy. Curr Microbiol 48:327-331.

Bextine B, Lampe D, Lauzon C, Jackson B and Miller TA (2005) Establishment of a genetically marked insect-derived symbiont in multiple host plants. Curr Microbiol 50:1-7.

Bezerra JDP, Santos MGS, Barbosa RN and Svedese VM (2013) Fungal endophytes from cactus Cereus jamacaru in Brazilian tropical dry forest: A first study. Symbiosis 60:53-63.

Bhattacharyya A, Stilwagen S, Ivanova N, D'Souza M, Bernal A, Lykidis A, Kapatral V, Anderson I, Larsen N, Los T, et al. (2002) Whole-genome comparative analysis of three phytopathogenic Xylella fastidiosa strains. Proc Natl Acad Sci U S A 99:12403-12408.

Blua MJ, Redak RA, Morgan DJW and Costa HS (2001) Seasonal flight activity of two Homalodisca species (Homoptera: Cicadellidae) that spread Xylella fastidiosa in southern California. J Econ Entomol 94:1506-1510.

Bourtzis K, Crook S, Daffonchio D, Durvasula R, Hanboonsong Y, Infante F, Lacava PT, Miller TA and Vega FE (2012) International entomology. Am Entomol 58:234-246.

Bové JM and Ayres AJ (2007) Etiology of three recent diseases of citrus in São Paulo State: Sudden death, variegated chlorosis and huanglongbing. IUBMB Life 59:346-354.

Bradbury JF (1991) CMI Descriptions of Pathogenic Fungi and Bacteria. No. 105. CAB International, Wallingford, 1049 p.

Burgain J, Gaiani C, Linder M and Scher J (2011) Encapsulation of probiotic living cells: From laboratory scale to industrial applications. J Food Eng 104:467-483.

Carvalho SA (2003) Regulamentação atual da Agência de Defesa Agropecuária para a produção, estocagem, comércio, transporte e plantio de mudas cítricas no Estado de São Paulo. Laranja 24:199-239.

Castle SJ, Byrne FJ, Bi JL and Toscano NC (2005) Spatial and temporal distribution of imidacloprid and thiamethoxam in citrus and impact on Homalodisca coagulata Wells populations. Pest Manag Sci 61:75-84.

Chang CJ, Garnier M, Zreik L, Rossetti V and Bove JM (1993) Culture and serological detection of the xylem-limited bacterium causing citrus variegated chlorosis and its identifica- 
tion as a strain of Xylella fastidiosa. Curr Microbiol 27:137-142.

Chanway CP (1997) Inoculation of tree roots with plant growth promoting soil bacteria: An emerging technology for reforestation. Forest Sci 43:99-112.

Chebotar NK, Malfanova MV, Shcherbakov AV, Ahtemakova GK, Luemberg B and Tikhenovich IA (2015) Endophytic bacteria in microbial preparations that improve plant development. Appl Biochem Micro 51:271-277.

Chen J and Civerali EL (2008) Morphological evidence for phages in Xylella fastidiosa. Virol J 5:e75.

Chen J, Jarret RL, Qin X, Hartung JS, Chang CJ and Hopkins DL (2000) 16SrDNA analysis of Xylella fastidiosa. Syst Appl Microbiol 23:349-354.

Collins MD and Jones D (1983) Reclassification of Corynebacterium flaccumfaciens, Corynebacterium betae, Corynebacterium oortii and Corynebacterium poinsettiae in the genus Curtobacterium, as Curtobacterium flaccumfaciens comb. nov. J Gen Microbiol 129:3545-3548.

da Silva FR, Vettore AL, Kemper EL, Leite A and Arruda P (2001) Fastidian gum: The Xylella fastidiosa exopolysaccharide possibly involved in bacterial pathogenicity. FEMS Microbiol Lett 203:165-171.

Dandekar AM, Gouran H, Ibáñez AM, Uratsu SL, Agüero CB, McFarland S, Borhani Y, Feldstein PA, Bruening G, Nacimento R, et al. (2012) An engineered innate immune defense protects grapevines from Pierce's disease. Proc Natl Acad Sci U S A 109:3721-3725.

Davis MJ, French WJ and Schaad NW (1981) Axenic culture of the bacteria associated with phony disease of peach and plum leaf scald. Curr Microbiol 5:311-331.

de Lima JEO, Miranda VS, Hartung JS, Brlansky RH, Coutinho A, Roberto SR and Carlos EF (1998) Coffee leaf scorch bacterium: Axenic culture, pathogenicity, and comparison with Xylella fastidiosa of citrus. Plant Dis 82:94-97.

Derrick KS and Timmer LW (2000) Citrus blight and other diseases of recalcitrant etiology. Annu Rev Phytopathol 38:181-205.

Doronina NV, Trotsenko YA, Tourova TP, Kuznetsov BB and Leisinger T (2000) Methylopila helvetica sp. nov. and Methylobacterium dichloromethanicum sp. nov. - novel aerobic facultatively methylotrophic bacteria utilizing dichloromethane. Syst Appl Microbiol 23:210-218.

Doronina NV, Trotsenko YA, Kuznetsov BB, Tourova TP and Salkinoja-Salonen MS (2002) Methylobacterium suomiense sp. nov. and Methylobacterium lusitanum sp. nov., aerobic, pink pigmented, facultatively methylotrophic bacteria. Int $\mathbf{J}$ Syst Evol Microbiol 52:773-776.

Dourado MN, Bogas AC, Pomini AM, Andreote FD, Quecine MC, Marsaioli AJ and Araújo WL (2013) Methylobacterium-plant interaction genes regulated by plant exudate and quorum sensing molecules. Braz J Microbiol 44:1331-1339.

Dourado MN, Santos DS, Nunes RL, Costa de Oliveira RLB, Oliveira MV and Araújo WL (2015) Differential gene expression in Xylella fastidiosa 9a5c during co-cultivation with the endophytic bacterium Methylobacterium mesophilicum SR1.6/6. J Basic Microbiol 55:1357-1366.

Duijff BJ, Gianinazzi-Pearson V and Lemanceau P (1997) Involvement of the outer membrane lipopolysaccharides in the endophytic colonization of tomato roots by biocontrol Pseu- domonas fluorescens strain WCS417r. New Phytol 135:325-344

Durvasula RV, Gumbs A, Panackal A, Kruglov O, Aksoy S, Merrifield RB, Richards FF and Beard CB (1997) Prevention of insect-borne disease: An approach using transgenic symbiotic bacteria. Proc Natl Acad Sci U S A 94:3274-3278.

Durvasula RV, Panackal A, Taneja J, Gumbs A, Kruglov O, Richards F and Beard CB (1999) A strategy for spreading antitrypanosomal genes in populations of the Chagas disease vector, Rhodnius prohxus. Ann Entomol Soc Am 92:937943.

Durvasula RV, Sundaram RK, Cordon-Rosales C, Pennington P and Beard BC (2003) Rhodnius prolixus and its symbiont, Rhodococcus rhodnii: A model for paratransgenic control of disease transmission. In: Bourtzis K and Miller TA (eds) Insect Symbiosis. CRC, Boca Raton, pp 83-95.

Ferreira Filho AS, Quecine MC, Bogas AC, Rossetto PB, Lima AOS, Lacava PT, Azevedo JL and Araújo WL (2012) Endophytic Methylobacterium extorquens expresses a hetero-

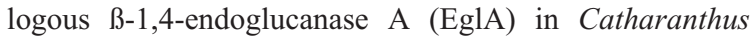
roseus seedlings, a model host plant for Xylella fastidiosa. World J Microbiol Biotechnol 28:1475-1481.

Freitag JH (1951) Host range of the Pierce's disease virus of grapes as determined by insect transmission. Phytopathology 41:920-934.

Freitag JH and Frazier NW (1954) Natural infectivity of leafhopper vectors of Pierce's disease virus of grape in California. Phytopathology 44:7-11.

Gai CS, Lacava PT, Quecine MC, Auriac MC, Lopes JRS, Araújo WL, Miller TA and Azevedo JL (2009) Transmission of Methylobacterium mesophilicum by Bucephalogonia xanthophis for paratransgenic control strategy of citrus variegated chlorosis. J Microbiol 47:448-454.

Gai CS, Dini-Andreote F, Andreote FD, Lopes JRS, Araújo WL, Miller TA, Azevedo JL and Lacava PT (2011) Endophytic bacteria associated to sharpshooters (Hemiptera: Cicadellidae), Insect vectors of Xylella fastidiosa subsp. pauca. J Plant Pathol Microbiol 2:102-109.

Gallego V, Garcia MT and Ventosa A (2005a) Methylobacterium hispanicum sp. nov. and Methylobacterium aquaticum sp. nov., isolated from drinking water. Int J Syst Evol Microbiol $55: 281-287$

Gallego V, Garcia MT and Ventosa A (2005b) Methylobacterium variabile sp. nov., a methylotrophic bacterium isolated from an aquatic environment. Int J Syst Evol Microbiol 55:14291433.

Gallego V, Garcia MT and Ventosa A (2005c) Methylobacterium isbiliense sp. nov., isolated from the drinking water system of Sevilla, Spain. Int J Syst Evol Microbiol 55:2333-2337.

Gallego V, Garcia MT and Ventosa A (2006) Methylobacterium adhaesivum sp. nov., a methylotrophic bacterium isolated from drinking water. Int J Syst Evol Microbiol 56:339-342.

Goheen AC, Raju BC, Lowe SK and Nyland G (1979) Pierce's disease of grapevines in Central America. Plant Dis Rep 63:788-792.

Golinska P, Wypij M, Agarkar G, Rathod D, Dahm H and Rai M (2015) Endophytic actinobacteria of medicinal plants: Diversity and bioactivity. Antonie van Leeuwenhoek 108:267-289.

Gonçalves FP, Stuchi ES, Lourenço SA, Kriss AB, Gottwald TR and Amorim L (2014) The effect of irrigation on develop- 
ment of citrus variegated chlorosis symptoms. Crop Prot 57:8-14.

Goodwin P and Purcell AH (1992) Pierce's Disease. In: Grape Pest Management. 2nd edition. University of California, Oakland, pp 76-84.

Green PN (1992) The genus Methylobacterium. In: Balows A, Trüper HG, Dworkin M, Harder W and Schleifer KH (eds) The Prokaryotes. 2nd edition. Springer, New York, pp 2342-2349.

Guilhabert MP and Kirkpatrick BC (2003) Transformation of Xylella fastidiosa with broad host range RSF 1010 derivative plasmid. Mol Plant Pathol 4:273-285.

Hallmann J, Quadt-Hallmann A, Mahaffee WF and Kloepper JW (1997) Bacterial endophytes in agricultural crops. Can J Microbiol 43:895-914.

Hallmann J, Quadt-Hallmann A, Rodríguez-Kábana R and Kloepper JW (1998) Interactions between Meloidogyne incognita and endophytic bacteria in cotton and cucumber. Soil Biol Biochem 30:925-937.

Hardoin PR, van Overbeek LS, Berg G, Pirttilä AM, Compant S, Campisano A, Döring M and Sessitsch A (2015) The hidden world within plants: Ecological and evolutionary considerations for defining functioning of microbial endophytes. Microbiol Mol Biol Rev 79:293-320.

Hartung JS, Beretta J, Brlansky RH, Spisso J and Lee RF (1994) Citrus variegated chlorosis bacterium: Axenic culture, pathogenicity, and serological relationships with other strains of Xylella fastidiosa. Phytopathology 84:591-597.

Hearon SS, Sherald JL and Kostka SJ (1980) Association of xylem-limited bacteria with elm, sycamore, and oak leaf scorch. Can J Bot 58:1986-1993.

Holt JG (1994) Xylella. Bergey's Manual of Determinative Bacteriology. 9th edition. Williams and Wilkins, London, pp 100-115.

Hopkins DL (1989) Xylella fastidiosa: Xylem-limited bacterial pathogen of plants. Annu Rev Phytopathol 27:271-290.

Hopkins DL and Purcell AH (2002) Xylella fastidiosa: Cause of Pierce's disease of grapevine and other emergent diseases. Plant Dis 86:1056-1066.

Hurwitz I, Fieck A, Read A, Hillesland H, Klein N, Kang A and Durvasula R (2011) Paratransgenic control of vector borne diseases. Int J Biol Sci 7:1334-1344.

Jourand P, Giraud E, Bena G, Sy A, Willems A, Gillis M, Dreyfus B and de Lajudie P (2004) Methylobacterium nodulans sp. nov., for a group of aerobic, facultatively methylotrophic, legume root-nodule-forming and nitrogen fixing bacteria. Int J Syst Evol Microbiol 54:2269-2273.

Kavino M, Harish S, Kumar N, Saravanakumar D, Damodaran T, Soorianathasundaram K and Samiyappan R (2007) Rhizosphere and endophytic bacteria for induction of systemic resistance of banana plantlets against bunchy top virus. Soil Biol Biochem 39:1087-1098.

Kirkpatrick B and Wilhelm M (2007) Evaluation of grapevine endophytic bacteria for control of Pierce's disease. In: Proceedings Pierce's Disease Research Symposium, San Diego, pp 203-206.

Kostka SJ, Tattar TA, Sherald JL and Hurtt SS (1986) Mulberry leaf scorch, new disease caused by a fastidious xyleminhabiting bacterium. Plant Dis 70:690-693.

Kozdrój J, Trevors JT and Van Elsas JD (2004) Influence of introduced potential biocontrol agents on maize seedling growth and bacterial community structure in the rhizosphere. Soil Biol Biochem 36:1775-1784.

Krügner R, Lopes MTVC, Santos JS, Beretta MJG and Lopes JRS (2000) Transmission efficiency of Xylella fastidiosa to citrus by sharpshooters and identification of two new vector species. In: Proceedings 14th Conference of International Organization of Citrus Virologists, Campinas, p 423.

Kung SH and Almeida RPP (2011) Natural competence and recombination in plant pathogenic Xylella fastidiosa. Appl Environ Microbiol 77:5278-5284.

Kuzina LV, Miller TA and Cooksey DA (2006) In vitro activities of antibiotics and antimicrobial peptides against the plant pathogenic bacterium Xylella fastidiosa. Lett Appl Microbio 42:514-520

Lacava PT and Azevedo JL (2013) Endophytic bacteria: A biotechnological potential in agrobiology system. In: Maheshwari DK, Sarah M and Aeron A (eds) Bacteria in Agrobiology: Crop Productivity. Springer-Verlag, Berlin, pp 1-44.

Lacava PT and Azevedo JL (2014) Biological control of insect-pest and diseases by endophytes. In: Verma VC and Gange AC (eds) Advances in Endophytic Research. Springer-Verlag, New Delhi, pp 231-243.

Lacava PT, Araújo WL, Marcon J, Maccheroni Jr W and Azevedo JL (2004) Interaction between endophytic bacteria from citrus plants and the phytopathogenic bacterium Xylella fastidiosa, causal agent of citrus variegated chlorosis. Lett Appl Microbio 39:55-59.

Lacava PT, Li WB, Araújo WL, Azevedo JL and Hartung JS (2006a) Rapid, specific and quantitative assays for the detection of the endophytic bacterium Methylobacterium mesophilicum in plants. J Microbiol Methods 65:535-541.

Lacava PT, Andreote FD, Araújo WL and Azevedo JL (2006b) Caracterização da comunidade bacteriana endofítica de citros por isolamento, PCR específico e DGGE. Pesq Agropec Bras 41:637-642.

Lacava PT, Li W, Araújo WL, Azevedo JL and Hartung JS (2007a) the endophyte Curtobacterium flaccumfaciens reduces symptoms caused by Xylella fastidiosa in Catharanthus roseus. J Microbiol 45:388-393.

Lacava PT, Parker J, Andreote FD, Dini-Andreote F, Ramirez JL and Miller TA (2007b) Analysis of the bacterial community in glassy-winged sharpshooter heads. Entomol Res 37:261266.

Lambais MR, Goldman MHS, Camargo LEA and Goldman GH (2000) A genomic approach to the understanding of Xylella fastidiosa pathogenicity. Curr Opin Microbiol 3:459-462.

Lampe DJ, Ackerley BJ, Rubin EJ, Mekalanos JJ and Robertson HM (1999) Hyperactive transposase mutants of the Himar1 mariner transposon. Proc Natl Acad Sci U S A 96:1142811433.

Lampe DJ, Walden KKO, Sherwood JM and Robertson HM (2000) Genetic engineering of insects with mariner transposons. In: Handler $\mathrm{A}$ and James $\mathrm{T}$ (eds) Insect Transgenesis: Methods and Applications. CRC Press, Boca Raton, pp 237-248.

Lampe D, Lauzon C and Miller TA (2006) Use of the E. coli $\alpha$-hemolysin secretion system in bacteria designed for symbiotic control of Pierce's disease in grapevines and sharpshooters. In: Proceedings Pierce's Disease Research Symposium, San Diego, pp 240-241. 
Lampe D, Kang A and Miller TA (2007) Native secretion systems for the grapevine endophyte Pantoea agglomerans useful for the delivery of anti-Xylella effector proteins. In: Proceedings Pierce's Disease Research Symposium, San Diego, pp 218-220.

Laranjeira FF, Pompeu Junior J, Harakava R, Figueiredo JO, Carvalho AS and Coletta-Filho HD (1998) Cultivares e espécies cítricas hospedeiras de Xylella fastidiosa em condição de campo. Fitopatol Bras 23:147-154.

Laranjeira FF, Amorim L, Bergamim-Filho A, Aguilar-Vildoso CI and Coletta-Filho HD (2005) Fungos, procariotos e doenças abióticas. In: Mattos Jr D, Negri JD, Pio RM and Pompeu Jr J (eds) Citros. Instituto Agronômico, Campinas, pp 532-538.

Lazarovits G and Nowak J (1997) Rhizobacteria for improvement of plant growth and establishment. HortScience 32:188-192.

Lee RF, Kerrick KS, Beretta MJG, Chagas CM and Rossetti V (1991) Citrus variegated chlorosis: A new destructive disease of citrus in Brazil. Citrus Industry 72:12-13.

Leu LS and Su CC (1993) Isolation, cultivation and pathogenicity of Xylella fastidiosa, the causal bacterium of pear leaf scorch disease in Taiwan. Plant Dis 77:642-646.

Li WB, Donadio LC, Beretta MJG, Rosetti V and Sempionato OR (1997a) Practical methods of resistance evaluation of citrus varieties to citrus variegated chlorosis. Proc Int Soc Citricult 1:276-279.

Li WB, Donadio LC, Beretta MJG, Rossetti V, Sempionato OR, Lemos EGM and Miranda V (1997b) Resistance or tolerance of citrus species and varieties to citrus variegated chlorosis. Proc Int Soc Citricult 1:283-285.

Li WB, Donadio LC, Sempionato OR, Stuchi ES, Rossetti V and Beretta MJG (1997c) Effect of 20 rootstocks on the severity of citrus variegated chlorosis (CVC) of sweet orange 'Pera' (C sinensis L. Osbeck). Proc Int Soc Citricult 1:286-289.

Li WB, Pria Jr WD, Lacava PM, Qin X and Hartung JS (2003) Presence of Xylella fastidiosa in sweet orange fruit and seeds and its transmission to seedlings. Phytopathology 93:953-958.

Lopes JRS, Beretta MJG, Harakava R, Almeida RPP, Krügner R and Garcia Júnior A (1996) Confirmação da transmissão por cigarrinhas do agente causal da clorose variegada dos citros, Xylella fastidiosa. Fitopatol Bras 21:343.

Lopes SA, Marcussi S, Torres SCZ, Souza V, Fagan C, França SC, Fernandes NG and Lopes JRS (2003) Weeds as alternative hosts of the citrus, coffee, and plum strains of Xylella fastidiosa in Brazil. Plant Dis 87:544-549.

Machado EC, Oliveira RF, Ribeiro RV, Medina CL, Stuchi ES, Marin FR, Silva JAB and Silva SR (2006) Fluxo de seiva e fotossíntese em laranjeira 'Natal'com clorose variegada dos citros. Pesq Agropec Bras 41:911-918.

Marques MV, Silva AM and Gomes SI (2001) Genetic organization of plasmid pXF51 from the plant pathogen Xylella fastidiosa. Plasmid 45:184-199.

McCoy RE, Thomas DL, Tsai JH and French WJ (1978) Periwinkle wilt, a new disease associated with xylem delimited rickettsialike bacteria transmitted by a sharpshooter. Plant Dis Rep 62:1022-1026.

McDonald IR, Doronina NV, Trotsenko YA, McAnulla C and Murrell JC (2001) Hyphomicrobium chloromethanicum sp. nov. and Methylobacterium chloromethanicum sp. nov., chloromethaneutilizing bacteria isolated from a polluted environment. Int J Syst Evol Micr 51:119-122.

Mendes R and Azevedo JL (2008) Valor biotecnológico de fungos endofíticos isolados de plantas de interesse econômico. In: Maia LC, Malosso E and Yano-Melo AM (eds) Micologia: Avanços no Conhecimento. Sociedade Brasileira de Micologia, Recife, pp 129-140.

Miller TA (2007) Symbiotic control in agriculture and medicine. Symbiosis 42:67-74.

Miller TA (2011) Paratransgenesis as a potential tool for pest control: Review of applied arthropod symbiosis. J Appl Entomol 135:474-478.

Mircetich SM, Lowe SK, Moller WJ and Nyland G (1976) Etiology of almond leaf scorch disease and transmission of the causal agent. Phytopathology 66:17-24.

Monteiro PB, Renaudin J, Jagoueix-Eveillard S, Ayres AJ, Garnier M and Bové JM (2001) Madagascar periwinkle (Catharanthus roseus): An experimental host plant for the citrus strain of Xylella fastidiosa. Plant Dis 85:246-251.

Nair DN and Padmavathy S (2014) Impact of endophytic microorganisms in plants, environments and humans. Sci World J 2014:e250693.

Nassar AH, El-Tarabily KA and Sivasithamparam K (2005) Promotion of plant growth by an auxin-producing isolate of the yeast Williopsis saturnus endophytic in maize (Zea mays L.) roots. Biol Fert Soils 42:97-108.

Newman LA and Reynolds CM (2005) Bacteria and phytoremediation: New uses for endophytic bacteria in plants. Trends Biotechnol 23:6-8.

Nunes LR, Rosato YB, Muto NH, Yanay GM, da Silva VS, Leite DB, Gonçalves ER, de Souza AA, Colleta Filho HD, Machado MA, et al. (2003) Microarray analyses of Xylella fastidiosa provide evidence of coordinated transcription control of laterally transferred elements. Genome Res 13:570-578.

Nyland GA, Goheen AC, Lowe SK and Kirkpatrick HC (1973) The ultrastructure of a rickettsia-like organism from a peach-tree affected with phony disease. Phytopathology 63:1275-1278.

Park YL, Perring TM, Farrar CA and Gispert C (2006) Spatial and temporal distributions of two sympatric Homalodisca spp. (Hemiptera: Cicadellidae): Implications for area wide pest management. Agric Ecosyst Environ 113:168-174.

Perring TM, Farrar CA and Blua MJ (2001) Proximity to citrus influences Pierce's disease in Temecula Valley vineyards. Calif Agric 55:13-18.

Petrini LE, Petrini O and Laflamme G (1989) Recovery of endophytes of Abiens balsamea from needles and galls of Paradiplosis tumifex. Phytoprotection 70:97-103.

Pierce NB (1892) The California Vine Disease. USDA Division of Vegetable Pathology Bulletin No. 2. USDA, Washington, D.C., 222 p.

Pillay VJ and Nowak J (1997) Inoculum density, temperature and genotype effects on in vitro growth promotion and epiphytic and endophytic colonization of tomato (Lycopersicum esculentum L.) seedlings inoculated with a pseudomonad bacterium. Can J Microbiol 43:354-361.

Podolick O, Ardanov P, Zaets I, Pirtilla AM and Kozyrovska N (2015) Reviving of the endophytic bacterial community as a putative mechanism of plant resistance. Plant Soil 388:367377. 
Purcell AH and Hopkins DL (1996) Fastidious xylem-limited bacterial plant pathogens. Annu Rev Phytopathol 34:131151.

Purcell AH and Saunders SR (1999) Fate of Pierce's disease strains of Xylella fastidiosa in common riparian plants in California. Plant Dis 83:825-830.

Quecine MC, Batista BD and Lacava PT (2014) Diversity and biotechnological potential of plant-associated endophytic bacteria. In: Ananda Kumar P and Govil JN (eds) Biotechnology, Vol. 2: Plant Biotechnology. Studium Press LLC, Houston, pp 377-423.

Rai M, Rathod D, Agarkar G, Dar M, Brestic M and Marostica Junior MR (2014) Fungal growth promotor endophytes: A pragmatic approach towards sustainable food and agriculture. Symbiosis 62:63-79.

Raju BC, Goheen AC and Frazier NW (1983) Occurrence of Pierce's disease bacteria in plants and vectors in California. Phytopathology 73:1309-1313.

Rathe AA, Pilkington LJ, Hoddle MS, Spohr LJ, Daugherty MP and Gurr GM (2014) Feeding and development of the glassy-winged sharpshooter, Homalidisca vitripennis, on Australian native plant species and implication for Australian biosecurity. PLoS One 9:e90410.

Raupach GS and Kloepper JW (1998) Mixtures of plant growth-promoting rhizobacteria enhance biological control of multiple cucumber pathogens. Phytopathology 88:11581164.

Redak RA, Purcell AH, Lopes JRS, Blua MJ, Mizell III RF and Andersen PC (2004) The biology of xylem fluid feeding insect vectors of Xylella fastidiosa and their relation to disease epidemiology. Annu Rev Entomol 49:243-270.

Reinhold-Hurek B and Hurek T (2011) Living inside plants: Bacterial endophytes. Curr Opin Plant Biol 14:435-443.

Rio RVM, Hu Y and Aksoy S (2004) Strategies of the home-team: Symbioses exploited for vector-borne disease control. Trends Microbiol 12:325-336.

Rogers EE and Stenger DC (2012) A conjugative $38 \mathrm{kB}$ plasmid is present in multiple subspecies of Xylella fastidiosa. PLoS One 7:e52131.

Rosenblueth M and Martinez-Romero E (2006) Bacterial endophytes and their interactions with hosts. Mol Plant Microbe Int 19:827-837.

Rossetti V, Garnier M, Bove JM, Beretta MJG, Teixeira ARR, Quaggio JA and deNegri JD (1990) Presence de bacteries dans le xyleme d'orangers atteints de chlorose variegee, unenovelle maladie des agrumes au Brasil. C R Acad Sci 310:345-349.

Rúa MA, McCulley RL and Mitchell CE (2013) Fungal endophyte infection and host genetic background jointly modulate host response to an aphid transmitted viral pathogen. J Ecol 101:1007-1018.

Rúa MA, McCulley RL and Mitchell CE (2014) Climate drivers, host identity and fungal endophyte infection determine virus prevalence in a grassland ecosystem. J Ecol 102:690-699.

Sanderlin RS and Heyderich-Alger KI (2000) Evidence that Xylella fastidiosa can cause leaf scorch disease of pecan. Plant Dis 84:1282-1286.

Sanderlin RS and Melanson RA (2006) Transmission of Xylella fastidiosa through pecan rootstock. HortScience 41:14551456.
Saponari M, Boscia D, Nigro F and Martelli GP (2013) Identification of DNA sequences related to Xylella fastidiosa in oleander, almond and olive trees exhibiting leaf scorch symptoms in Apulia (Southern Italy). J Plant Pathol 95:668.

Schaad NW, Postnikova E, Lacy G, Fatmi M and Chang C-J (2004) Xylella fastidiosa subspecies: X. fastidiosa subsp. piercei, subsp. nov., $X$. fastidiosa subsp. multiplex, subsp. nov., X. fastidiosa subsp. pauca, subsp. nov. Syst Appl Microbiol 27:290-300.

Sharma VK and Nowak J (1998) Enhancement of verticillium wilt resistance in tomato transplants by in vitro co-culture of seedlings with a plant growth promoting rhizobacteria (Pseudomonas sp. strain PsNJ). Can J Microbiol 44:528536.

Sherald JL, Wells JM, Hurtt SS and Kostka SJ (1987) Association of fastidious xylem-limited bacteria with leaf scorch in red maple. Plant Dis 71:930-933.

Simpson AJG, Reinach FC, Arruda P, Abreu FA, Acencio M, Alvarenga R, Alves LMC, Araya JE, Baia GS, Baptista CS, et al. (2000) The genome sequence of the plant pathogen Xylella fastidiosa. Nature 406:151-159.

Smith IM, McNamara DG, Scott PR, Holderness M and Burger B (1997) Quarantine Pests for Europe. 2nd edition. CAB International, Wallingford, $1425 \mathrm{p}$.

Sturz AV and Matheson BG (1996) Populations of endophytic bacteria which influence host-resistance to Erwinia-induced bacterial soft rot in tubers. Plant Soil 184:265-271.

Sturz AV, Christie BR and Matheson BG (1998) Association of bacterial endophyte populations from red clover and potato crops with potential for beneficial allelopathy. Can J Microbiol 44:162-167.

Sturz AV, Christie BR and Nowak J (2000) Bacterial endophytes: Potential role in developing sustainable systems of crop production. Crit Rev Plant Sci 19:1-30.

Summer EJ, Enderle CJ, Ahern J, Gill JJ, Torres CP, Appel DN, Black MC, Young R and Gonzalez CF (2010) Genome and bacterial analyses of phage Xfas53 and related prophages of Xylella fastidiosa. J Bacteriol 192:179-190.

Suryanarayanan TS (2013) Endophyte research: Going beyond isolation and metabolic documentation. Fungal Ecol 6:561568.

Takiya DM, McKamey SH and Cavichioli RR (2006) Validity of Homalodisca and of $H$. vitripennis as the name for glassywinged sharpshooter (Hemiptera: Cicadellidae: Cicadellinae). Ann Entomol Soc Am 99:648-655.

Tor M, Mantel SH and Ainsworth C (1992) Endophytic bacteria expressing beta-glucuronidase cause false positives in transformation of dioscorea species. Plant Cell Rep 11:452-456.

Urakami T, Araki H, Suzuki K and Komagata K (1993) Further studies of the genus Methylobacterium and description of Methylobacterium aminovorans sp. nov. Int J Syst Evol Microbiol 43:504-513.

Van Aken B, Peres CM, La Fferty-Doty S, Yoon JM and Schnoor JL (2004) Methylobacterium populi sp. nov. a novel aerobic, pink pigmented, facultatively methylotrophic, methaneutilizing bacterium isolated from poplar trees (Populus deltoids x nigra DN34). Int J Syst Evol Microbiol 54:11911196.

Van Sluys MA, de Oliveira MC, Monteiro-Vitorello CB, Mitald CY, Furlan RL, Camargo LEA, da Silva ACR, Moon DH, Takita MA, Lemos EGM, et al. (2003) Comparative analy- 
ses of the complete genome sequences of Pierce's disease and citrus variegated chlorosis strains of Xylella fastidiosa. $\mathbf{J}$ Bacteriol 185:1018-1026.

Varani AM, Monteiro-Vitorello CB, de Almeida LGP, Souza RC, Cunha OL, Lima WC, Civerolo E, Van Sluys MA and Vasconcelos ATR (2012) Xylella fastidiosa: Comparative genomic databases is an information resource to explore the annotation, genomic features and biology of different strains. Genet Mol Biol 35:149-152.

Verma P, Yadav AK, Khanna KS, Kumar S, Saxena AK and Suman A (2015) Alleviation of cold stress in wheat seedlings y Bacillus amyloliquefaciens iari-hhs2-30 an endophytic psychrotolerant K-solubilizing bacterium from NW Indian himalayas. Nat J Life Sci 12:105-110.

Weinbreck F, Bodnár I and Marco ML (2010) Can encapsulation lengthen the shelf-life of probiotic bacteria in dry products? Int J Food Microbiol 136:364-367.

Wells JM, Raju BC, Hung H-Y, Weisburg WG, Mandelco-Paul L and Brenner DJ (1987) Xylella fastidiosa gen. nov., sp. nov: Gram-negative, xylem limited, fastidious plant bacteria related to Xanthomonas spp. Int J Syst Evol Microbiol 37:136-143.
Wells JM, Raju BC, Thomson JM and Lowe SK (1981) Evidence of the common etiology of phony peach and plum leaf scald diseases. Phytopathology 71:1156-1161.

Wistrom C and Purcell AH (2005) The fate of Xylella fastidiosa in vineyard weeds and other alternate hosts in California. Plant Dis 89:994-999.

Wood AP, Kelly DP, McDonald IR, Jordan SL, Morgan TD, Khan S, Murrell JC and Borodina E (1998) A novel pink pigmented facultative methylotroph, Methylobacterium thiocyanatum sp. nov., capable of growth on thiocyanate or cyanate as sole nitrogen sources. Arch Microbiol 169:148158.

Yamada K and Komagata K (1972) Taxonomic studies on coryneform bacteria. IV. Morphology, cultural, biochemical, and physiological characteristics. J Gen Appl Microbiol 18:399-416.

Zinnier DK, Lambrecht N, Harris B, Feng Z, Kuezmarski D, Higley P, Ishimaru CA, Arunakumari A, Barletta RG and Vidaver AK (2002) Isolation and characterization of endophytic colonizing bacteria from agronomic crops and prairie plants. Appl Environ Microbiol 68:2198-2208.

\section{Associate Editor: Carlos F. M. Menck}

License information: This is an open-access article distributed under the terms of the Creative Commons Attribution License (type CC-BY), which permits unrestricted use, distribution and reproduction in any medium, provided the original article is properly cited. 